\title{
HEARD ISLAND AND MCDONALD ISLANDS
}

\author{
by Ewan Mclvor
}

(with two text-figures)

McIvor, E. 2007 (23:xi): Heard Island and McDonald Islands. Papers and Proceedings of the Royal Society of Tasmania 141(1): 7-10.

https://doi.org/10.26749/rstpp.141.1.7 ISSN 0080-4703. Australian Antarctic Division, Channel

Highway, Kingston, Tasmania 7054, Australia.

The sub Antarctic Heard Island and McDonald Islands (HIMI) group is an Australian external territory located in the Indian Ocean sector of the Southern Ocean. The island group was inscribed on the World Heritage list in 1997 for its outstanding natural universal values, primarily due to the relative absence of human influence on the natural environment. The Territory also forms part of a 65000 $\mathrm{km}^{2}$ Marine Reserve, declared under the Environment Protection and Biodiversity Conservation Act 1999 in 2002 to protect the conservation values of the islands and the surrounding unique and vulnerable marine ecosystems. The Territory and Marine Reserve are managed by the Australian Antarctic Division of the Department of Environment and Water Resources, in accordance with the Heard Island and McDonald Islands Marine Reserve Management Plan 2005, which aims to address a range of potential human pressures, most notably the risk of introduced species.

Key Words: sub-Antarctic islands, Heard Island, McDonald Islands.

\section{LOCATION AND PHYSICAL CHARACTERISTICS}

The Heard Island and the McDonald Islands (HIMI) group is located in the Indian Ocean sector of the Southern Ocean at approximately $53^{\circ} \mathrm{S} 73^{\circ} 30^{\prime} \mathrm{E}$, some $4000 \mathrm{~km}$ southwest of Western Australia, $4700 \mathrm{~km}$ southeast of Africa and 1000 $\mathrm{km}$ north of the Antarctic continent. The nearest land is the French territory of Îles Kerguelen, approximately $440 \mathrm{~km}$ to the northwest (fig. 1). Together, these island groups form the only surface exposures of the Kerguelen Plateau, one of the world's largest submarine plateaux.

Heard Island is approximately $43 \mathrm{~km}$ long from the tip of the Laurens Peninsula in the northwest to the tip of Elephant Spit in the southeast, and covers an area of approximately $368 \mathrm{~km}^{2}$ (see fig. 2). The landforms on Heard Island have been sculpted by the interaction of diverse processes, including a long and complex geological history (Quilty 2007), multiple episodes of volcanic activity, erosion and transport by wind, water and glaciers, moulding by vigorous marine processes and the influence of gravity (Kiernan \& McConnell 1999).

Heard Island is dominated by Big Ben, a heavily glaciated and roughly circular volcano with a base diameter of $18-20 \mathrm{~km}$ and maximum elevation of $2745 \mathrm{~m}$ (Quilty \& Wheller 2000). Due to its height and location south of the Antarctic Convergence, approximately $70 \%$ (or 257 $\mathrm{km}^{2}$ ) of the island is covered by glaciers and a further $2 \%$ by year-round snow (Ruddell 2006). There are 12 major glaciers radiating towards the sea from the summit of Big Ben or from the peaks of Laurens Peninsula (Ruddell 2006). As a result of regional warming the extent of the glaciers is decreasing, with corresponding development, expansion and coalescing of coastal lagoons and ice-free areas (Kiernan \& McConnell 2002).

Numerous minor eruptions and other volcanic events, such as plumes, have been observed on Big Ben since 1947 (Quilty \& Wheller 2000). Recent volcanic activity has dramatically altered the McDonald Islands, located approximately $40 \mathrm{~km}$ to the west. Sometime during the $1990 \mathrm{~s}$, the main island doubled in size — to approximately $2.5 \mathrm{~km}^{2}$ - and became joined via a low-lying isthmus to the previously separate Flat Island (Quilty 2007).
The climate is strongly influenced by the islands' location south of the Antarctic Convergence in a zone of strong and persistent westerly winds - the "furious 50s" and by local factors, such as the perennial ice cover and mountainous nature of Heard Island. The maritime setting leads to low seasonal and daily temperature ranges, persistent and generally low cloud cover, frequent precipitation and strong winds. Records from Atlas Cove, near sea level at the northwestern end of the island, show a monthly average temperature range from $0.0-4.2^{\circ} \mathrm{C}$, monthly average wind speeds of $26-33.5 \mathrm{~km} / \mathrm{hr}$ and annual precipitation of 1.3-1.9 m (water equivalent) (Thost \& Allison 2006).

\section{HISTORY}

Due to the isolation and persistently severe weather and sea conditions, human activity has been, and remains, limited. Although sealing activity had been under way at Îles Kerguelen since the 1770 s, the first confirmed sighting of Heard Island was made only in 1853 by Captain John Heard on the riental, with the McDonald Islands sighted the following year by Captain William McDonald on the Samarang (Downes \& Downes 2006).

The first landing at Heard Island was by a sealing expedition in February 1855, and over 40 vessels made more than 100 voyages to the island in the following three decades seeking oil from Southern Elephant Seals Mirounga leonina (Linnaeus, 1758) (Downes \& Downes 2006). Brief visits were also made by whalers and sealers in the early 1900 s. Some evidence of these early activities remains, with items such as stone platforms, hut ruins, oil barrels and graves still present at several coastal sites (McGowan \& Lazer 1989, McGowan 2000, Hughes \& Lazer 2000).

Several brief scientific visits to Heard Island were conducted by expeditions from several nations in the late nineteenth and early twentieth centuries, but the first extensive scientific studies occurred during the operation of the Australian National Antarctic Research Expedition (ANARE) station at Atlas Cove between December 1947 and March 1955. As with the sealing-era artefacts, the remains of the ANARE station are included in Australia's Register of the National Estate for their historic importance. 


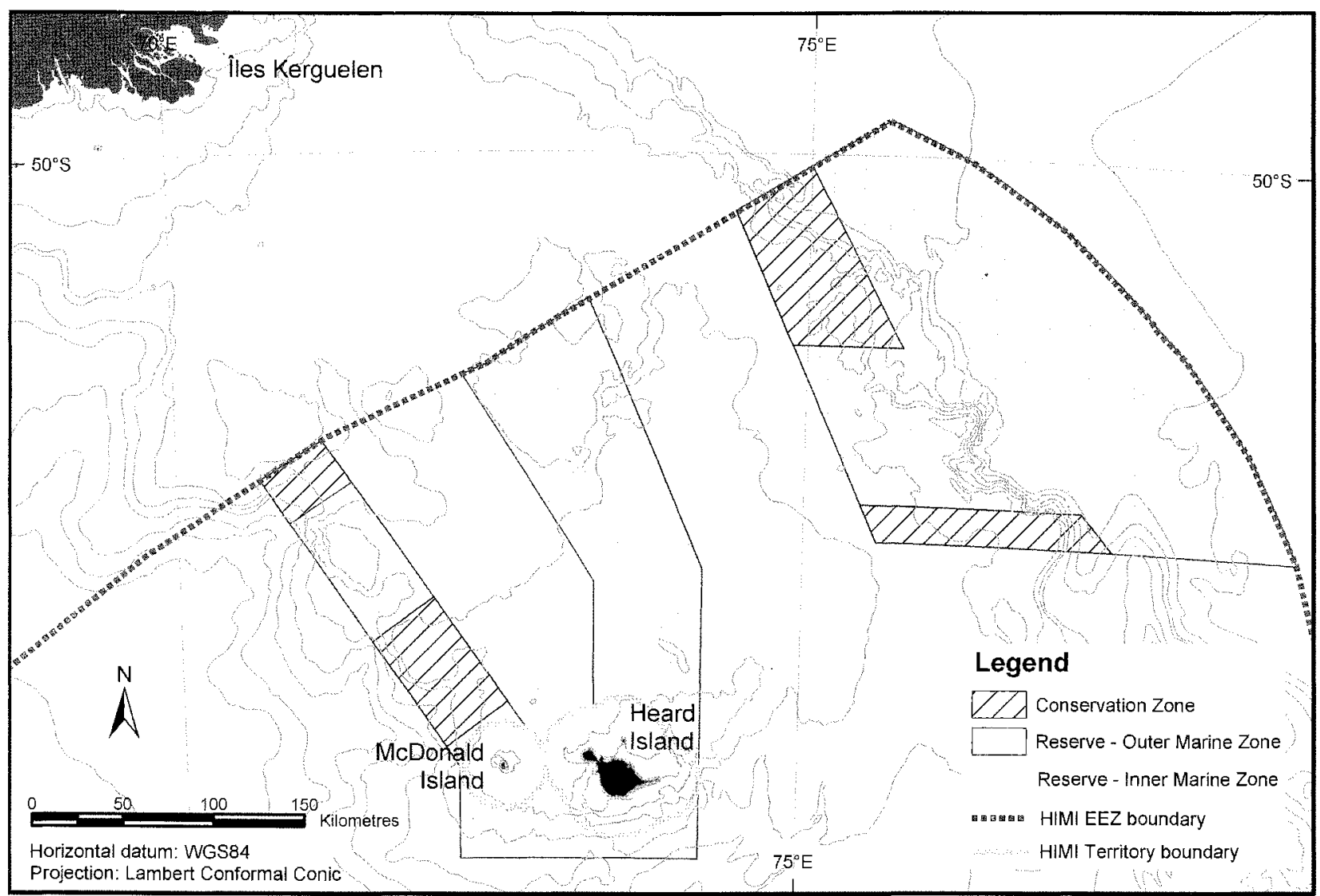

FIG. 1 - Heard Island and McDonald Islands Marine Reserve boundaries.

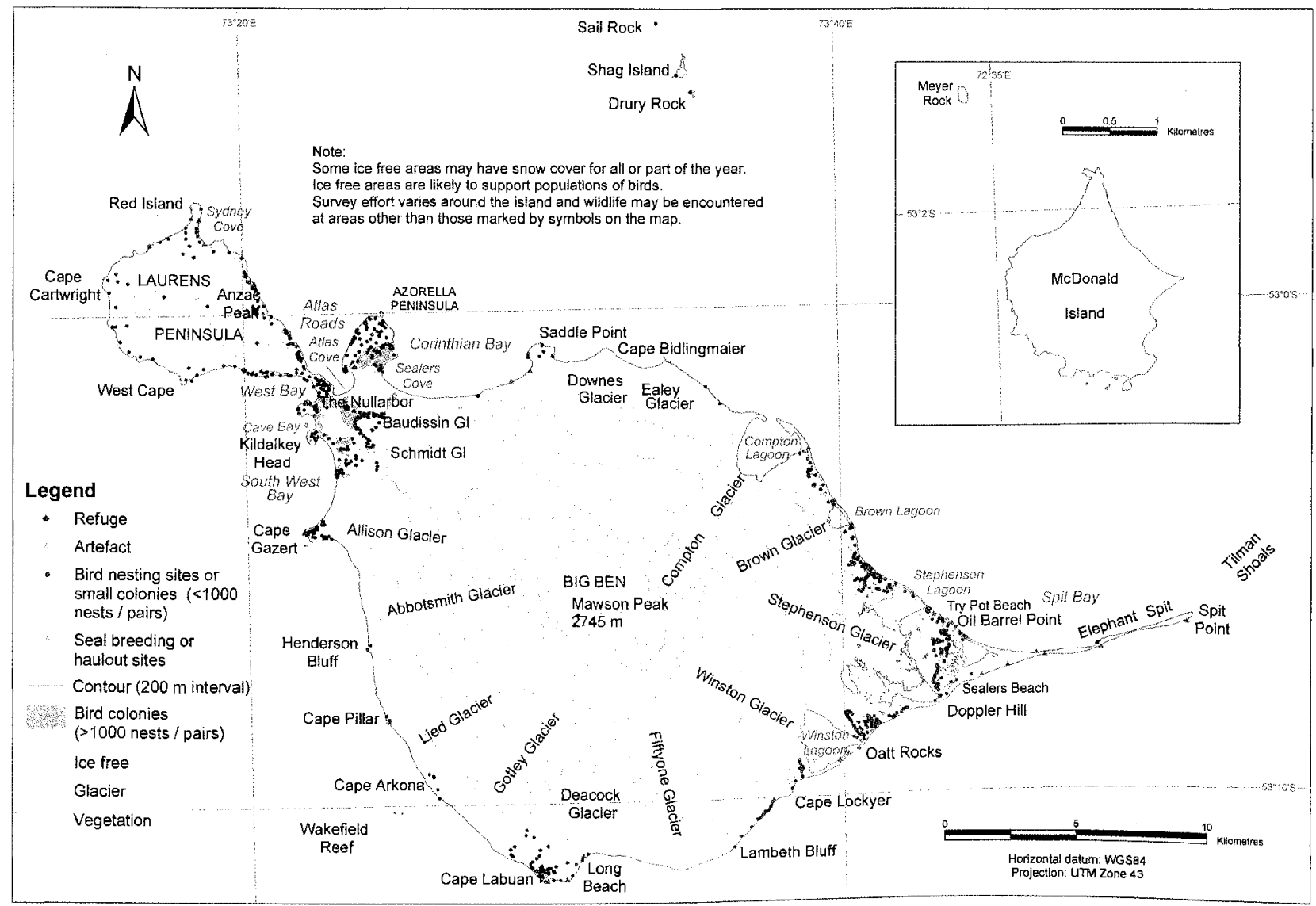

FIG. 2 - General map of Heard Island and McDonald Islands. 
Periodic Australian research expeditions have been made to Heard Island since the Australian ANARE station was closed in 1955, and occasional visits have also been made by other nations. There are only two brief recorded landings at McDonald Island, in 1971 and 1980. The high cost and substantial logistical requirements for visits to HIMI have meant that private expeditions and commercial tourist visits have been infrequent and brief.

Terrestrial and marine research, as part of the Australian Antarctic science program, is currently the main human activity at Heard Island and research expeditions are mounted every few years. However, commercial fishing in the adjacent waters is the most frequent human activity in the region.

\section{FLORA AND FAUNA}

The relatively late discovery of the islands, combined with minimal human visitation over the twentieth century, mean that theflora and fauna has recently been subjected to minimal impact by local human activities. Importantly, Heard Island is the largest sub-Antarctic island with no known humanintroduced plant species or vertebrate predators.

The terrestrial flora is typically sub-Antarctic, with low-growing herbaceous flowering plants and bryophytes comprising the major components of the vegetation. Substantial vegetation covers almost $20 \mathrm{~km}^{2}$ of Heard Island, mostly in coastal areas at elevations below $250 \mathrm{~m}$ (Scott \& Bergstrom 2006, Scott \& Ryan 2004). With 12 vascular plant species on Heard Island (and only five of these recorded from McDonald Island) (Jenkin 1987), HIMI has the lowest number of vascular plant species of any major sub-Antarctic island group (Scott \& Bergstrom 2006).

Non-vascular plants contribute substantially to the overall biodiversity of Heard Island, with 62 recorded species of bryophyte and 71 recorded species of lichen (Scott \& Bergstrom 2006). With climate warming and increasing availability of new ice-free habitat, some plant species are spreading and modifying vegetation communities, some of which are also increasing in distribution. Seven vegetation communities are currently recognised: open-cushionfield vegetation - characterised by Azorella selago Hook.f. cushions interspersed with bryophytes, small vascular species and bare ground - being the most widespread and abundant (Scott \& Bergstrom 2006; Bergstrom et al. 2002). A survey at McDonald Island in 1980 found fewer communities than Heard Island (Jenkin 1997), and recent volcanic activity will have altered the vegetation.

Fifteen species of seabird have been recorded as breeding on Heard Island (Woehler \& Croxall 1991), including two endemic species (Heard Island Cormorant Phalacrocorax atriceps (King, 1828) and Heard Island Sheathbill Chionis minor nasiconis Reichenow, 1984), four listed threatened species (Southern Giant Petrel Macronectes gianteus (Gmelin, 1789), the aforementioned Heard Island Cormorant, Antarctic Tern Sterna vittata Gmelin, 1789, and Wandering Albatross Diomeda exulans Linnaeus, 1758). Penguins are by far the most abundant birds, and four breeding species are present, including two listed threatened species (Macaroni Eudyptes chrysolophus (Brandt, 1837) and Rockhopper Eudyptes chrysocome (Forster, 1781)). Volcanic activity at McDonald Island may have affected bird populations, but earlier surveys estimated Macaroni Penguin populations on Heard and McDonald Islands as approximately two million birds each (Woehler \& Croxall 1991).
Three breeding seal species are recorded, including two listed threatened species (Southern Elephant Seal Mirounga leonina and Sub-Antarctic Fur Seal Arctocephalus tropicalis (Gray, 1872)). Relative to other Southern Ocean islands, Heard Island supports a low number of terrestrial invertebrate species (Chown et al. 2006).

Heard Island has a number of small wetland sites scattered around its coastal perimeter, including areas of wetland vegetation, lagoons, pool complexes, rugged rocky shores, sandy shores and the Elephant Spit. Many of these wetland areas are currently separated by glaciers. Wetlands have also been recorded on McDonald Island but, following recent volcanic activity, their present extent is unknown.

\section{MARINE ENVIRONMENT}

The waters surrounding the islands contain important and unique benthic species and assemblages, representative portions of the different habitat types in the region, nursery grounds for commercial fish species, and near-surface waters where land-based marine predators concentrate their local foraging activities. These special qualities were recognised in the declaration of the HIMI Marine Reserve in 2002 which, at $65000 \mathrm{~km}^{2}$, is one of the largest marine protected areas in the world.

\section{CONSERVATION AND MANAGEMENT}

The enactment of legislation and the implementation of measures to ensure formal protection of the conservation values of the HIMI Territory and surrounding region have been a priority since Australia assumed responsibility for administration and management in 1947. The Heard Island and McDonald Islands Act 1953 made provisions for the protection of wildlife and the making of ordinances for the administration of the islands, and the Environment Protection and Management Ordinance 1987 (EPMO) made under the Act established a legal regime for the protection of indigenous plants and animals, including the obligation to prepare a management plan for the Territory and the requirement for a permit to enter or undertake activities in the Territory. The Heard Island Wilderness Reserve Management Plan was made under the EPMO and came into effect in 1996. The management plan provided priorities for decisions that would affect the Territory, defined appropriate uses and activities, outlined management areas and contained management strategies for protecting the Territory's values.

In 1998 the HIMI region was identified in Australia's Oceans Policy (Commonwealth of Australia 1998) as one of five areas where the Australian Government would preferentially pursue a marine park, to ensure Australia's temperate and sub-Antarctic waters were incorporated in the comprehensive and representative system of marine protected areas and to help protect Australia's unique marine biodiversity. The HIMI Marine Reserve was declared under the Environment Protection and Biodiversity Conservation Act 1999 (EPBC Act) in October 2002 for the purpose of "protecting the conservation values of Heard Island and McDonald Islands and the adjacent unique and vulnerable marine ecosystems".

The Marine Reserve includes the islands and surrounding territorial sea (the HIMI Territory) plus additional marine areas extending in parts to the exclusive economic zone 
(EEZ) boundary. It is designated as an IUCN category Ia strict nature reserve, to be managed primarily for science and environmental monitoring. The management objectives include:

- protecting conservation values of HIMI, the territorial sea and the adjacent EEZ including:

- the World Heritage and cultural values of the HIMI Territory

- the unique features of the benthic and pelagic environments

- representative portions of the different marine habitat types

- marine areas used by land-based marine predators for local foraging activities.

- providing an effective conservation framework which will contribute to the integrated and ecologically sustainable management of the HIMI region as a whole

- providing a scientific reference area for the study of ecosystem function within the HIMl region

- adding representative examples of the HIMI EEZ to the National Representative System of Marine Protected Areas.

The HIMI Territory and Marine Reserve are managed by the Australian Antarctic Division (AAD) of the Australian Government Department of the Environment and Water Resources, in accordance with the Heard Island and McDonald Islands Marine Reserve Management Plan (Australian Antarctic Division 2005).

The management plan addresses legal requitements arising from both the EPBC Act and the EPMO, action plans for a range of threatened species and numerous applicable international agreements, including the World Heritage Convention, Ramsar (wetlands) Convention, Bonn (migratory species) Convention, bilateral migratory birds agreements with China and Japan, and the Agreement on the Conservation of Albatrosses and Petrels.

It incorporates strict measures to minimise the risk of introducing non-native species, to avoid disturbance to the flora and fauna, and to prevent adverse impacts of waste and pollution. It also recognises the important contribution that scientific research at HIMI can make to understanding the effects of climate change, and to sustainably managing the surrounding marine environment. It obliges humans to act as "thoughtful, responsible and privileged visitors", requites adherence to an environmental code of conduct for visitors, and defines a suite of management zones to facilitate protection of areas that are susceptible to the impacts of human activities — such as vegetated areas, listed threatened species and sensitive geological features - and to confine human activity to sites that can sustain it.

Fishing is prohibited within the Marine Reserve, but an Australian commercial fishery operates in other areas within the HIMI EEZ. The fishery falls within the area of application of the Convention for the Conservation of Antarctic Marine Living Resources (CCAMLR) and is managed in accordance with the Heard Island and McDonald Islands Fishery Managenent Plan 2002 by the Australian Fisheries Management Authority (AFMA).

Other Australian Government agencies with management responsibiliry for activities in the HIMI region include the Australian Customs Service and Australian Defence Force, which are responsible for border protection and security, and the Australian Maritime Safety Authority, which is responsible for shipping and marine safety.

\section{REFERENCES}

Australian Antarctic Division 2005: Heard Island and McDonald Islands Marine Reserve Management Plan. Australian Antarctic Division: $198 \mathrm{pp}$.

Bergstrom, D.M., Whinam, J. \& Belbin, L. 2002: A classification of subantarctic Heard Island vegetation. Arctic, Antarctic and Alpine Research 34: 169-177.

Chown, S.L., Greenslade, P. \& Marshall, D.J. 2006: Terrestrial invertebrates of Heard Island, In Green, K. \& Woehler, E. (eds): Heard Island: Southern Ocean Sentinel. Surrey Beatty \& Sons, Chipping Norton: 91-104.

Commonwealth of Australia. 1998: Australia's Oceans Policy. Environment Australia, Canberra: $52 \mathrm{pp}$.

Downes, M. \& Downes, E. 2006: Sealing at Heard Island in the nineteenth century. In Green, K. \& Woehler, E. (eds):Heard Island: Southern Ocean Sentinel. Surrey Beatty \& Sons, Chipping Norton: 184-195.

Hughes, S.J. \& Lazer, E. 2000: Importance of "Historic Sites" on Heard Island for protection of scientific resources and environmental management of a World Heritage Site. Papers and Proceedings of the Royal Society of Tasmania 133(2): 21-77.

Jenkin, J.F. 1997: Vegetation of the McDonald Islands, subAntarctic. Polar Biology 18: 260-272.

Kiernan, K. \& McConnell, A. 1999: Geomorphology of the SubAntarctic Australian Territory of Heard Island-McDonald Island. Australian Geographer 30(2): 159-195.

Kiernan, K. \& McConnell, A. 2002: Glacier retreat and meltlake expansion at Stephenson Glacier: Heard Island World Heritage Area. Polar Record 38(207): 297-308.

McGowan, A. 2000: On their own: towards an analysis of sealers' sites on Heard Island. Papers and Proceedings of the Royal Society of Tasmania 133(2): 61-70.

McGowan, A. \& Lazer, F. 1989: Heard Island archaeological survey (1986-1987). Unpublished report to Australian Heritage Commission, Canberra: $131 \mathrm{pp}$.

Quilty, P.G. 2007: Origin and evolution of the sub-Antarctic islands. Papers and Proceedings of the Royal Society of Tasmania 141(1): $\mathrm{xx}-\mathrm{xx}$.

Quilty, P.G. \& Wheller, G. 2000: Heard Island and the McDonald Islands: a window into the Kerguelen Plateau. Papers and Proceedings of the Royal Society of Tasmania 133(3): $1-12$.

Ruddell, A. 2006: An inventory of present glaciers on Heard Isiand and their historical variations. In Green, K. \& Woehler, E. (eds): Heard Island: Southern Ocean Sentinel. Surrey Beatty \& Sons, Chipping Norton: 28-51.

Scott, J.J. \& Bergstrom, D.M. 2006: Vegetation of Heard Island and the McDonald Islands. In Green, K. \& Woehler, E. (eds): Heard Island: Southern Ocean Sentinel. Surrey Beatty \& Sons, Chipping Norton: 69-90.

Scott, J.J. \& Ryan, U. 2004: Heard Island vegetation mapping from orthophotos derived from non-metric photography. Australian Antarctic Data Centre - SnoWhite Metadata.

Thost, D. \& Allison, I. 2006: The climate of Heard Island. In Green, K. \& Woehler, E. (eds): Heard Island: Southern Ocean Sentinel. Surrey Beatty \& Sons, Chipping Norton: 62-68.

Woehler, E. \& Croxall, J. 1991: Status and conservation of the seabirds of Heard Island and the McDonald Islands In Seabird - Status and Conservation: a Supplement. ICBP Technical Publication 11, International Council for Bird Preservation, Cambridge: 263-277.

(accepted 24 September 2007) 